\title{
Teaching Design of the Accounting Course based on Entrepreneurship Training
}

\author{
(PRESENTED)
}

\author{
LI Qian \\ Rongzhi College of Chongqing Technology and Business University \\ rzxylq@126.com
}

\begin{abstract}
This paper first analyzes the connotation and composition of the entrepreneurial capacity, points out the disadvantages of the existing accounting teaching based on teaching content of the non-accounting majors' basic course of accounting and then designs the practical teaching system of accounting according to the CBET teaching design model. The design distinguishes it from the existing teaching content of accounting and highlights the entrepreneurship training of university students, hoping to make contribution to it.
\end{abstract}

Keywords-Entrepreneurship ; Accounting ; Teaching Design

At present, the difficult employment of university graduates is no longer a fresh topic but an important problem needing urgent solution. The 18th National Party Congress proposes to encourage entrepreneurship to create more employment opportunities, and the country, each province and city also have issued some policies, which provides new ideas and powerful public opinion supports for solving the employment problem of university graduates. Despite the good external environment for university graduates' entrepreneurship, according to the latest data, only a small number of university graduates have chosen to start an enterprise, the results still have large space for promotion, and the cases of failure can be found everywhere. One of the reasons for it is that the entrepreneurship training still lags far behind the training of other abilities in the present cultivation goals of university students. The entrepreneurship training needs the change of the university teaching in idea, system and talent training mode, which undoubtedly proposes a new requirement on the current university education. On this basis, this paper studies the existing problems in the course of accounting and redesigns the practical teaching system based on the entrepreneurship training, hoping to make contribution to it.

I. CONNOT ATION AND COMPOSITION OF ENT REPRENEURSHIP

The so-called entrepreneurship refers to the ability or strength for starting a succes sfulbusiness. Although different scholars have disputes on the concept of entrepreneurship, according to the theory of entrepreneurship, there is a consensus on the entrepreneurial process. It generally includes the following four stages: the first is to identify and evaluate the market; the second is to prepare and write a business plan; the third is to determine and obtain the business resources; and the last is to manage the new enterprise. Those four stages all reflect entrepreneurship. The first stage reflects the ability to identify the market opportunities and make innovation; the second stage reflects the ability to obtain the resources; the third stage reflects the planning ability; and the last stage reflects the ability to manage new business and risks. In addition, the above abilities do not exist in one stage alone. Entrepreneurship is a kind of comprehensive ability to a large extent. Thus, in order to improve entrepreneurship, it's necessary to focus on the training of the comprehensive ability rather than a single one.

As a comprehensive ability, entrepreneurship is mainly composed of the following three parts: the values of the entrepreneur, the entrepreneurial behavior capacity and the resource conditions for entrepreneurship [1], as shown in Fig.1. For university students, the entrepreneurship training can start from the values of the entrepreneur, the entrepreneurial behavior capacity. On this basis, this paper studies how to redesign the teaching system of the accounting course to achieve the purpose of training the university students' entrepreneurship.

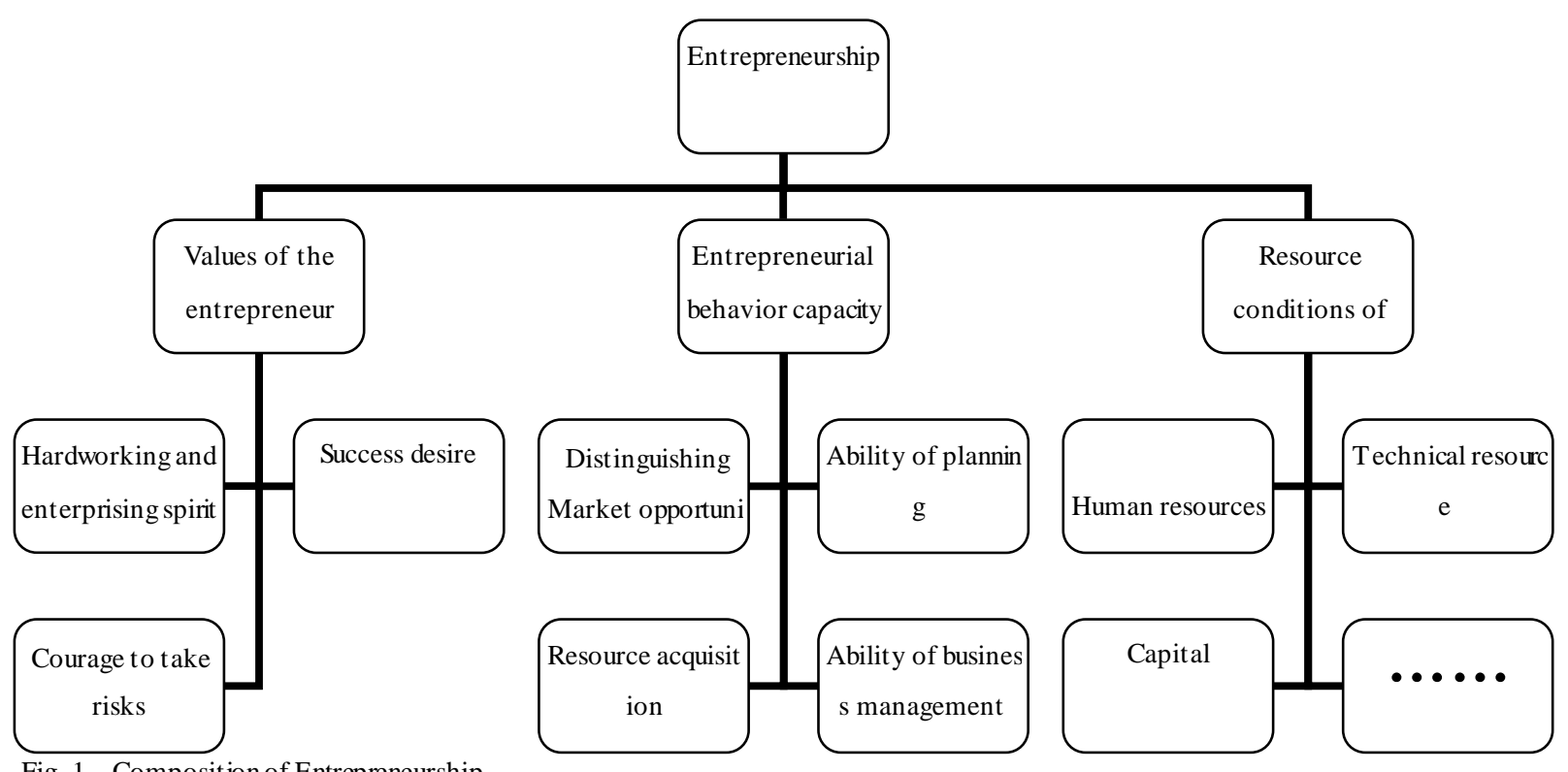

Fig. 1. Composition of Entrepreneurship

\section{The TeAChing St atus of The CuRrent ACCOUnTING} COURSE

Thanks to the key subject construction project of Rongzhi college agency for funding.

As a common business language, accounting reflects and supervises the financial situation and management results of the accounting entity through the disclosure of the accounting 
information. The accounting information provides reference for the users to make the economic decisions. Thus, in most colleges and universities, accounting is taken as the basic course of the non-accounting majors of admin istration. Next, it will focus on the analysis of the present teaching status of accounting opened for the non-accounting majors of adminis tration.

\section{A. No Clear Teaching Goal}

At present, the teaching goal of the majors in accounting can be basically unified, but for the non-accounting students, due to the different internal relationship between different specialties and accounting, the teaching goal is not clear [2] . In addition, there is generally no clear goal of entrepreneurship training in the existing teaching of accounting.

\section{B. Lack of Unification in the Teaching Content}

This is due to the unclear teaching goal. The existing teaching contents of accounting for the non-accounting majors are generally in the following modes: 1. teaching the same content of basic accounting of the accounting majors with the generation process of the accounting information as the focus and around the special accounting methods ---account setup, double-entry accounting, accounting document, account book, costing, property verification, statement preparation, etc. and emphasizing accounting and supervision functions; 2. taking the mode of basic accounting plus financial accounting to teach the contents of basic accounting but also six elements of accounting and the item accounting in six elements. The focus of the teaching mode is still accounting; 3 . in addition to the contents of basic accounting and financial accounting, teaching the knowledge of management accounting and financial statement analysis, but there is no clear teaching goal and main teaching line in this mode. As a result, the students just feel there are many miscellaneous knowledge points related to accounting. After learning, they just remember a few professional terms but know nothing about them.

\section{Single Teaching Method}

So far, despite the constant advancement of the teaching methods, the common mode in practical teaching has been always the spoon-feeding method of teaching which puts more emphasis on the rules, practice and skills than the principle and theory and quality education. The students are cultivated with the traditional learning habits of listening to the teacher and taking notes in class and finishing the homework after class. When the examination comes, they cram for it to memorize the knowledge points mechanically. This teaching method rarely combines the practical cases and has no practical course, which makes the students feel difficult to understand accounting. On the other hand, it fails to arouse the students' enthusiasm for self-thinking, which is not conducive to improving their ability of understanding and analyzing problems and improving their entrepreneurship.

From the perspective of the request of entrepreneurship, it's necessary to make students learn to observe how an enterprise is started and managed from the angle of accounting and how to make good use of the accounting information in the operation and management for economic decisions. Based on the cultivation of entrepreneurship, it makes the teaching design for the accounting course in next section.

\section{TEACHING DESIGN OF ACCOUNTING ACCORDING TO THE CBET MODEL}

According to the CBET design of the teaching design, as shown in Fig.2 the CBET teaching design model is the abilitybased education training model. Ability is integrated with knowledge, motivation, experience, skill and personality characteristics to become the condition for being competent for a job or task. Through training, people's potential can be converted into ability [3].

The first part has analyzed the composition of entrepreneurship. Next, it will design the teaching system of the accounting course of non-accounting majors based on the CBET teaching model.

A. Characteristics of the Students


The so-called non-accounting specialty is a relative concept. It refers to other specialties except accounting. Of course, not all non-accounting specialties need to open this course. Generally speaking, it's mainly opened for the specialties of admin istration. Thus, the target students in this paper mainly refer to the non-accounting students of administration. Among those students, only a small number will engage in the accounting practice in the future and most just use the accounting information to make the economic decisions. Therefore, it's particularly important for them to understand and interpret the accounting information. However, to better understand and interpret the accounting information, it needs to understand how the accounting information is generated first.

B. Determination of the Teaching Goal

According to different characteristics of different teaching objects, when teaching this course, the teachers should pay attention to explore the students' subjective initiative and focus on training their basic ability to analyze and solve the accounting problems, so as to train their entrepreneurship. Specifically, the teachers should let students realize the accounting knowledge is related to each person and the whole country and plays an important role. Based on the training appeal of entrepreneurship, the teaching goals of the accounting course are determined as: knowing the generation of the accounting information on the basis of getting familiar with and understanding the basic knowledge and methods of accounting; focusing on interpreting the accounting information, making use of the accounting information for economic decisions and introducing some knowledge points of internal control. The difference from the previous teaching goals is that a new enterprise is taken as an example in the link of generating the accounting information to explain the economic businesses the enterprise may encounter, so as to cultivate the mode of accounting thinking for self-employ ment in the future. At the same time, it timely introduces the internal control points needing attention. 


\section{Construction of the Teaching Content System}

Then, starting from the teaching goals for the nonaccounting majors, how to build the accounting teaching system? First of all, it should be adapted to the teaching goal, or ensure to achieve the established teaching goal. Then, the content is more comprehensive than before, so it is worth noting that comprehensiveness does not mean going into all details. Finally, it should focus on the students and strive to stimulate their interest, so as to improve the teaching effect. Based on this, the teaching content of the accounting course for non-accounting majors is constructed as follows:

Table 1 The Teaching Content System of Accounting

\begin{tabular}{|c|c|c|}
\hline $\begin{array}{c}\text { Serial } \\
\text { No. }\end{array}$ & $\begin{array}{l}\text { Name of the } \\
\text { Teaching Module }\end{array}$ & Main Teaching Contents \\
\hline 1 & $\begin{array}{c}\text { Basic Knowledge } \\
\text { of Accounting }\end{array}$ & $\begin{array}{l}\text { Introducing some basic theories } \\
\text { and methods of accounting }\end{array}$ \\
\hline 2 & $\begin{array}{c}\text { Accounting of the } \\
\text { Economic } \\
\text { Business }\end{array}$ & $\begin{array}{l}\text { Taking a new enterprise as an } \\
\text { example to introduce how to } \\
\text { prepare accounts and account } \\
\text { the economic businesses }\end{array}$ \\
\hline 3 & $\begin{array}{c}\text { Interpretation of the } \\
\text { Accounting } \\
\text { Information }\end{array}$ & $\begin{array}{l}\text { Focusing on the interpretation } \\
\text { of the accounting statements } \\
\text { and the introduction of the } \\
\text { accounting analy sis methods }\end{array}$ \\
\hline 4 & $\begin{array}{c}\text { Internal Control } \\
\text { Knowledge of the } \\
\text { Enterprises }\end{array}$ & \\
\hline
\end{tabular}

In above modules, the first three are deepened layer upon layer. Students should learn the basic knowledge of the previous modules to lay a foundation for learning the latter. The last one can be integrated into the second module. It's hoped that through learning the knowledge of the above modules, the non-accounting majors can reserve the knowledge required by the users of the accounting information and establish the preliminary accounting thinking. It's also conductive to improving the students' entrepreneurship.

D. Testing of the Teaching Result

In addition to the traditional homework, experiment report and examination paper, the following three evaluation ways are introduced to test the teaching result. The first is to carry out the deliberative teaching to test the teaching result. Students are divided into groups for the cooperative learning. The groups focus on question discussion. The questions are designed with the goal of digesting the theoretical contents of the unit and associated with the practical business to highlight the guiding significance of the theory to the practice. As a result, the students jump out the small circle of accounting, but are not isolated from it. They can have a vision of big accounting view. It can cultivate their comprehensive ability of self-study, word organization and expression, problem analysis and solution, communication, unity and cooperation. The second is to do sand table exercises to test and consolidate the teaching result. It simulates the running condition of an enterprise through the intuitive enterprise running sand table, so that the students can truly experience the whole process of enterprise operation and running, learn how to make best use of the limited resources, perceive the scientific thinking mode and the management law of the enterprises, and finally improve their entrepreneurship and avoid risks. The third is to promote the exercises with competitions by encouraging the students to participate in Challenge cup College Students Entrepreneurship Competition, China Innovation \& Entrepreneurship Competition and others and developing the corresponding competition management system and award measures to mobilize their enthusiasm for participation, improve their interest and ultimately achieve the goal of improving their entrepreneurial ability.

\section{E. Specific Implementation of the Teaching Course}

In the specific implementation of the teaching task of the accounting course, the teachers should adopt some new teaching methods like case teaching, problem-based learning, enlightening teaching and deliberative teaching to create the interactive teaching scene between the teacher and the students, so as to improve their interest, stimulate the thinking expansion and realize the goal of entrepreneurship training.

\section{F. Regular Detection and Revision of the Teaching Goal}

In addition, it's necessary to detect and revise the teaching quality system purposefully to make the teaching quality achieve the intended goal. It can be started from the following two aspects: the first is to employ several students in each class as the teaching information reporters and use some teaching quality monitoring indexes to know the teaching status of all teachers and the students' suggestions and opinions on the teaching organization in real time, so as to rectify the existing problems timely. The second is to make the tracking survey on the graduates, especially some entrepreneurial graduates about their feedback on the teaching in the universities, so as to adjust and improve the professional teaching cultivation plan and teaching contents and methods and better cultivate more students with entrepreneurship.

Of course, in order to train entrepreneurship, it's far from enough to start from one or several courses. It needs the sufficient and solid professional knowledge. Only when the students have the profound professional knowledge and extensive non-professional knowledge, can they analyze the situation correctly, recognize the development trends of things, grasp the overall situation and finally realize the business goals.

\section{REFERENCES}

[1] Jing T ang and Yanfu Jiang, "Theoretical Construct and Empirical Study on the Concept of Entrepreneurial Compet ence", Journal of Science of Science and Management of S.\& T.,pp. 52-57, 08.2008

[2] Xiao Ling Wang,'Thougts on the teaching of non-Accounting Majors", Journal of Adult Education School of Inner Mongollia Finace and Economics Shool, pp. 65-68, 05.2009

[3] Chen $\mathrm{Xu}$, "Ability Exploitation of Station Based on CBET - Pattern of Ability Monetary Standard Course", Journal of Adult Education School of He bei University of Technology, Vo.121 No.2,Jun. 2005. 